\section{Prevalence of falls in elderly in Brazil: a countrywide analysis}

\author{
Prevalência de quedas em idosos no Brasil: \\ uma análise nacional
}

\author{
1 Faculdade de Medicina, \\ Universidade Federal de \\ Pelotas, Pelotas, Brasil. \\ 2 Faculdade de Enfermagem \\ e Obstetrícia, Universidade \\ Federal de Pelotas, Pelotas, \\ Brasil. \\ 3 Programa de Pós-graduação \\ em Epidemiologia \\ Universidade Federal de \\ Pelotas, Pelotas, Brasil. \\ Correspondence \\ F. V. Siqueira \\ Departamento de Medicina \\ Social, Faculdade de \\ Medicina, Universidade \\ Federal de Pelotas. \\ Av. Duque de Caxias 250, \\ Pelotas, RS \\ 96030-002, Brasil. \\ fcvsiqueira@uol.com.br
}

\begin{abstract}
We conducted a cross-sectional study of a sample of 6,616 elderly living in urban areas of $100 \mathrm{mu}$ nicipalities in 23 Brazilian states, who responded to questions on the occurrence of falls in the 12 months prior to the interview, and occurrence of fractures due to the falls. The prevalence of falls among the elderly was 27.6\% (95\%CI: 26.5-28.7). Among those reporting falls, $11 \%$ had suffered fractures as a result. Of the elderly, 36\% had received guidance about the precautions necessary to prevent falls, and about $1 \%$ had required surgery. Falls were associated with female gender, older age, low socioeconomic status, obesity and sedentary lifestyles. The prevalence of falls differed significantly between the North and other regions of Brazil. The study shows a high prevalence of falls, and underlines the need for preventive strategies targeting modifiable risk factors.
\end{abstract}

Aged; Accidental Falls; Prevalence

\author{
Fernando Vinholes Siqueira 1 \\ Luiz Augusto Facchini 1 \\ Denise Silva da Silveira 1 \\ Roberto Xavier Piccini 1 \\ Elaine Tomasi 1 \\ Elaine Thumé 2 \\ Suele Manjourany Silva ${ }^{3}$ \\ Alitéia Dilélio 3
}

\section{Introduction}

The demographic transition characterized by population aging is a global phenomenon resulting from factors that include lower fertility rates and increased life expectancy. It is estimated that the proportion of elderly in the population will grow $300 \%$ by 2025 , and this process of aging is expected to cause major impact on countries' economies and health systems 1 .

Falls are one of the most important health hazards at this stage of life, which has drawn researchers' interest to improving the understanding and prevention of what are considered modifiable risk factors, and to building the human resources necessary to provide preventive care for this population.

Studies by researchers in different regions of the world currently report different prevalences for the outcome "falls among the elderly" 2,3,4,5,6. In Beijing, China, Yu et al. ${ }^{2}$ found a prevalence of falls of $18 \%$ associated with age from 60 to 70 years, female sex, low level of physical activity, poor eyesight, living alone, and other health problems, such as diabetes. In Latin American countries, Reyes-Ortiz et al. 3 found prevalences of $27 \%$ in Uruguay, $28.5 \%$ in Argentina, and close to $34 \%$ in Santiago, Chile, and Mexico City. In Brazil, Mota et al. 4 studied an elderly population in the Rio de Janeiro municipal area, finding prevalence of falls of $30.3 \%$ associated with female sex, advanced age, divorce, living alone, poor 
health conditions, low functional capacity, and little life satisfaction. In a study in Brazil's South and Northeast regions, Siqueira et al. 6 found the prevalence of falls to be $34.8 \%$, and significantly higher $(40.1 \%)$ among women. In a study of a cohort of elderly by Perracini \& Ramos 5, in one of the surveys, about $30 \%$ reported at least one fall in the previous year.

Although many studies on the subject have been conducted in Brazil 4,5,6, there is still little information on falls in a national sample. This study is intended to determine the prevalence of falls in Brazil and the health status of the elderly as regards falls, in terms of guidance received on avoiding falls, the occurrence of fractures, and the need to use the health system to undergo surgery.

\section{Materials and methods}

A cross-sectional population-based study was conducted with a sample of elderly aged 60 years or more, residing in the urban areas of $100 \mathrm{mu}$ nicipalities in 23 of Brazil's states - Acre, Alagoas, Bahia, Ceará, Espírito Santo, Goiás, Maranhão, Mato Grosso, Mato Grosso do Sul, Minas Gerais, Pará, Paraíba, Paraná, Pernambuco, Piauí, Rio de Janeiro, Rio Grande do Norte, Rio Grande do Sul, Rondônia, Santa Catarina, São Paulo, Sergipe and Tocantins - in the country's five geographical regions.

The representative sample of the population of elderly in Brazil was located by: (a) municipal population size in five categories (less than 10,$000 ; 10,000$ to less than 20,$000 ; 20,000$ to less than 100,000; 100,000 to less than 1 million; and 1 million or more), (b) census tracts, and (c) domiciles, forming a complex framework of samples at multiple levels of sampling unit 7,8. The municipalities and census tracts were selected by territorial division and the tract grid used by the official 2000 population census (Instituto Brasileiro de Geografia e Estatística. Censo Demográfico 2000. http://www.ibge.gov.br). After listing Brazil's municipalities by population size, the study municipalities were selected by random draw. In each municipality selected, tracts were selected by random draw in proportion to the number of valid tracts and the population size.

All the elderly in the selected tracts responded to the study questions, and data were collected by 55 interviewers with over 40 hours special training, who used a personal digital assistant (PDA) for data collection. Once collected, data were stored on personal computers and the datasets were transferred immediately to the study coordinators at Pelotas Federal University (UFPel) by
Internet. For quality control purposes, $5 \%$ of the interviews were selected by random draw at most three days after the first interview. Another quality control strategy used was to compare the geographical coordinates of each domicile, as given by the data recorded on the PDA, with the location in the census tract as mapped by the IBGE, so as to monitor the sample distribution over the area of the tract, thus avoiding the possibility of biases.

The questionnaire used was standardized and pre-tested, and the outcome was operationalized by the question: "Have you fallen at any time in the past year?" 9. All the individuals responded about receiving guidance on environmental precautions to prevent falls. Those who reported falls were also asked about the occurrence of fractures resulting from the fall, and the need for surgery because of the fracture. The questions used were: "Did a fracture occur in any of these falls?" and “Did you need surgery because of that fracture?".

The independent variables included in the analysis were: sex; age (60 to 69 years, 70 to 79 years, 80 years or more); marital status (with or without partner); socioeconomic status (as classified by the Associação Brasileira de Empresas de Pesquisa; http://www.abep.org); body mass index (BMI) in four categories [underweight (> $\left.18.5 \mathrm{~kg} / \mathrm{m}^{2}\right)$, normal $\left(18.5 \mathrm{~kg} / \mathrm{m}^{2}\right.$ to $\left.24.9 \mathrm{~kg} / \mathrm{m}^{2}\right)$, overweight $\left(25 \mathrm{~kg} / \mathrm{m}^{2}\right.$ to $\left.29.9 \mathrm{~kg} / \mathrm{m}^{2}\right)$ and obesity $\left.\left(>30 \mathrm{~kg} / \mathrm{m}^{2}\right)\right]$; sedentary in leisure time, according to the cutoff point taken from the International Physical Activity Questionnaire (IPAQ) of < 150 minutes of physical activity per week 10 .

The descriptive analyses included calculating proportions and the corresponding 95\% confidence intervals $(95 \% \mathrm{CI})$. In the crude analysis, the prevalence of falls was calculated for each group of independent variables, and the level of significance was ascertained using Wald tests for heterogeneity and linear trend. The adjusted analysis was performed by Poisson regression 11 , with robust estimates of variance, adjusted calculation of prevalence ratios (PRs), 95\%CI, and significance values by the test mentioned above. All the analyses were performed using the Stata 9.2 statistics package (Satat Corp., College Station, USA).

The study protocol was approved (No. 152/07, 23 November 2007) by the Ethics Committee of the UFPel School of Medicine, and informed consent was obtained from all participants. The authors declare having no conflicting interest in the present study. 


\section{Results}

Of an expected total of 6,624 elderly, 6,616 were interviewed, representing loss of $0.2 \%$. In the final sample, the margin of error in estimating prevalence of falls was 1.1 percentuals points. In evaluating the associations, the study achieved $80 \%$ power to detect prevalence ratios of 1.2 or greater as significant to a $95 \%$ level of confidence.

The study sample included 59\% women, $42 \%$ of socioeconomic status C, $58 \%$ with partner, $20 \%$ with BMI classified as obese, and $86.5 \%$ sedentary during their leisure time (Table 1). Mean age was 70.9 years (standard deviation - SD = 8.0), from 60 to 104 years old, with $15.8 \%$ aged 80 years or more.

The prevalence of falls in the sample was $27.6 \%$ (95\%CI: 26.5-28.7). The prevalence of falls by geographical region of Brazil ranged from $18.6 \%$ (95\%CI: 15.3-21.8) in the North Region to $30 \%$ (95\%CI: 28.2-31.9) in the Southeast Region. The prevalences displayed no difference or trend by size of municipality (Figures $1 \mathrm{a}$ and $1 \mathrm{~b}$ ). Of respondents who reported falls during the past year, $53.5 \%$ had suffered a single fall, $21.2 \%$ mentioned two falls, $13.3 \%$ three falls, and $12 \%$ four or more falls. Of those who reported falls, $11 \%$ had suffered fractures as a result.

Table 2 shows the prevalence of falls among elderly by regions of Brazil, stratified by age. In the North Region the prevalences of falls among the 60 to 69 year-olds $(15.3 \% ; \mathrm{p}=0.004)$ and 70 to 79 year-olds $(18 \% ; \mathrm{p}<0.001)$ were lower than in the other regions.

The crude analysis showed that falls were more frequent in the female sex $(\mathrm{p}<0.001)$, in the older elderly $(\mathrm{p}<0.001)$, in the obese elderly ( $p<0.001)$, and in those who were sedentary during their leisure time $(p<0.001)$. In the crude analysis, there is a tendency for falls to associate with socioeconomic status, although it is not possible to specify in what category. Living with a partner proved protective against falls as compared with those who lived alone $(\mathrm{p}<0.001)$. In the adjusted analysis, falls continued to associate with female sex, advanced age, obesity and sedentary leisure. In the same way, the tendency to associate with socioeconomic level also persisted (Table 3 ).

The study furnished evidence in Brazil of prevalences relating to health status and the need for health care for the elderly with regard to falls. Although $36 \%$ of the elderly studied had received guidance on environmental precautions with a view to avoiding falls, nonetheless the prevalence of falls was $27.6 \%$. Of those who suffered falls, $3 \%$ suffered fractures as a result and $0.7 \%$ needed surgery because of the fracture (Figure 2).
Table 1

Description of sample of elderly in 23 states in Brazil.

\begin{tabular}{|c|c|}
\hline Variables (n) & Prevalence (\%) \\
\hline \multicolumn{2}{|l|}{$\operatorname{Sex}(6,616)$} \\
\hline Male & 41.0 \\
\hline Female & 59.0 \\
\hline \multicolumn{2}{|c|}{ Age $(6,061)$ [years] } \\
\hline $60-69$ & 50.1 \\
\hline $70-79$ & 34.1 \\
\hline 80 or more & 15.8 \\
\hline \multicolumn{2}{|c|}{ Marital status $(6,614)$} \\
\hline No partner & 41.9 \\
\hline With partner & 58.1 \\
\hline \multicolumn{2}{|c|}{ Socioeconomic status $(6,346)$} \\
\hline A & 2.2 \\
\hline B & 14.8 \\
\hline C & 41.8 \\
\hline $\mathrm{D}$ & 36.2 \\
\hline$E$ & 5.0 \\
\hline \multicolumn{2}{|c|}{ Body mass index $(5,383)$} \\
\hline Underweight & 4.1 \\
\hline Normal & 38.8 \\
\hline Overweight & 37.1 \\
\hline Obesity & 20.0 \\
\hline \multicolumn{2}{|c|}{ Sedentarism in leisure $(6,594)$} \\
\hline No & 13.5 \\
\hline Yes & 86.5 \\
\hline
\end{tabular}

Source: Projeto AQUARES, Universidade Federal de Pelotas, 2009.

\section{Discussion}

A prevalence of falls found for the population of elderly in Brazil was $27.6 \%$. This result is very similar to some of the results found by ReyesOrtiz et al. ${ }^{3}$, who report $27 \%$ for Uruguay, $28.5 \%$ for Argentina, and close to $34 \%$ for Santiago and Mexico City. Another study in Turkey returned a prevalence of $31.9 \%$ for falls among the elderly in the previous 12 months 12 .

As regards the prevalence of falls found for the different regions of Brazil, the prevalence of $26.9 \%$ found for the South Region was lower than the $33.5 \%$ reported by Carvalho et al. 9 for the town of Pelotas, Rio Grande do Sul, and also the $38.3 \%$ of the study by Gonçalves et al. 13 in the town of Rio Grande, Rio Grande do Sul. Nonetheless, it is important to stress that these studies considered institutionalized elderly over 65 years of age. Another study of exclusively female elderly in the municipality of Rio de Janeiro found a prevalence of $23.3 \%$, which is lower than the 
Prevalence of falls in the elderly by geographical region $(p<0.001)$ and size of municipality in Brazil $(p<0,42)$. UFPel, AQUARES, 2009

1a) Geographical region

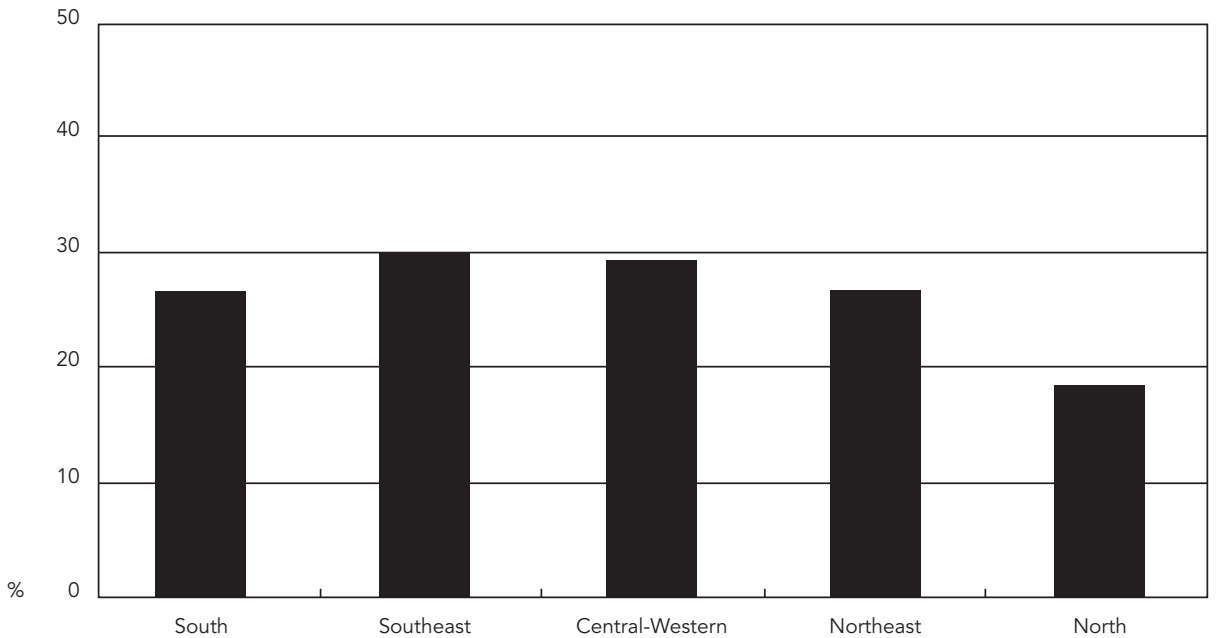

1b) Size of municipality

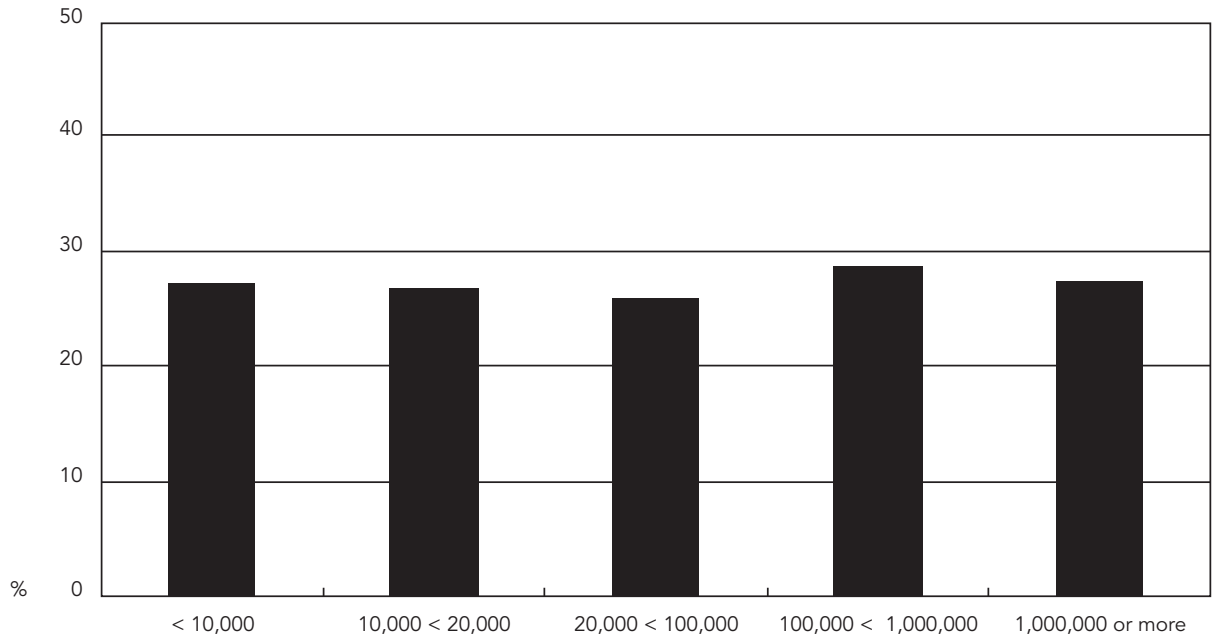

$30 \%$ we found for the Southeast Region 14 . These comparisons should be viewed with caution because of the methodological differences among the studies, although they are believed to be appropriate to discussing the values found here for the different regions of Brazil. The low prevalence of falls in Brazil's North Region (18.6\%) is striking when compared with the other regions. Our hypothesis for this finding relates to the lower prevalence of falls found in the younger elderly age groups. We strongly suggest that further studies be made with a view to understanding better the reasons for these lower prevalences.

Among the elderly who suffered falls, $11 \%$ reported at least one fracture as a result of the event. A recent study of a sample of elderly resi- 
Prevalence of falls in the elderly by geographical region of Brazil, stratified by age.

\begin{tabular}{|c|c|c|}
\hline \multirow[t]{2}{*}{ Region } & \multicolumn{2}{|c|}{ Falls } \\
\hline & No & Yes \\
\hline \multicolumn{3}{|l|}{ North } \\
\hline \multicolumn{3}{|l|}{ Age (years) } \\
\hline $60-69$ & 84.7 & 15.3 * \\
\hline $70-79$ & 82.0 & 18.0 ** \\
\hline 80 or more & 69.5 & $30.5^{\star \star \star}$ \\
\hline \multicolumn{3}{|l|}{ Northeast } \\
\hline \multicolumn{3}{|l|}{ Age (years) } \\
\hline $60-69$ & 76.5 & 23.5 \\
\hline $70-79$ & 72.7 & 27.3 \\
\hline 80 or more & 64.4 & 35.6 \\
\hline \multicolumn{3}{|l|}{ Southeast } \\
\hline \multicolumn{3}{|l|}{ Age (years) } \\
\hline $60-69$ & 73.9 & 26.1 \\
\hline $70-79$ & 67.6 & 32.4 \\
\hline 80 or more & 61.9 & 38.1 \\
\hline \multicolumn{3}{|l|}{ South } \\
\hline \multicolumn{3}{|l|}{ Age (years) } \\
\hline $60-69$ & 75.0 & 25.0 \\
\hline $70-79$ & 75.2 & 24.8 \\
\hline 80 or more & 60.8 & 39.2 \\
\hline \multicolumn{3}{|l|}{ Mid-west } \\
\hline \multicolumn{3}{|l|}{ Age (years) } \\
\hline $60-69$ & 73.7 & 26.3 \\
\hline $70-79$ & 70.6 & 29.4 \\
\hline 80 or more & 61.3 & 38.7 \\
\hline
\end{tabular}

Source: Projeto AQUARES, Universidade Federal de Pelotas, 2009.

* $p=0.004$ ( $p$-value for the 60 to 69 year old category in the various different regions);

** $p<0.001$ ( $p$-value for the 70 to 79 year old category in the various different regions);

${ }^{\star \star \star} p=0.654$ ( $p$-value for the 80 years or older category in the various different regions).

dents in the catchment areas of primary health care centers in Brazil's South and Northeast regions found a prevalence of $12 \%{ }^{6}$. Another study in Spain came to the same result, which strongly reinforces the findings of this study 15 .

Our study showed a greater likelihood of falls among female elderly. This result is consistent with the findings of other studies in the scientific literature, although the prevalence of falls found among women in Brazil was higher than found by the study in Turkey 12 . Our result shows a lower prevalence of falls among women than found in the Brazilian study of populations of elderly by primary health care (PHC) catchment area 6 (32.1\% as against $40.1 \%$ ), although the likelihood of falls (PR) was exactly the same, i.e., about $50 \%$. One hypothesis for this finding is that the popu- lation studied in this Brazil-wide sample has different characteristics from the notoriously disadvantaged populations of PHC catchment areas. That hypothesis is strengthened by our finding that falls tend to an association when socioeconomic status is changed, although the category cannot be specified.

Several studies have shown clearly the trend for prevalence of falls to increase with age. Our results show the same positive association between this outcome and increasing age 6,16,17,18,19. Meanwhile, the variables BMI and sedentarism revealed that obese and sedentary individuals showed greater likelihood of suffering falls. Similar results are reported by Siqueira et al. 6 in their study of a population in PHC catchment areas. That finding shows the importance of interven- 
Prevalence, crude and adjusted analysis of the outcome "falls in the elderly" in Brazil.

\begin{tabular}{|c|c|c|c|c|c|}
\hline Male & 21.2 & 1.00 & & 1.00 & \\
\hline Female & 32.1 & $1.51(1.39-1.65)$ & & $1.50(1.36-1.66)$ & \\
\hline Age (years) & & & $<0.001$ * & & $<0.001$ * \\
\hline $70-79$ & 27.9 & $1.14(1.04-1.25)$ & & $1.13(1.02-1.25)$ & \\
\hline 80 or more & 37.1 & $1.52(1.38-1.66)$ & & $1.46(1.30-1.64)$ & \\
\hline Marital status & & & $<0.001$ & & 0.79 \\
\hline No partner & 31.7 & 1.00 & & 1.00 & \\
\hline With partner & 24.6 & $0.78(0.72-0.84)$ & & $0.99(0.90-1.09)$ & \\
\hline C & 27.6 & $1.22(0.89-1.67)$ & & $1.31(0.87-1.95)$ & \\
\hline $\mathrm{D}$ & 29 & $1.28(0.93-1.76)$ & & $1.30(0.87-1.94)$ & \\
\hline$E$ & 31.1 & $1.37(0.97-1.95)$ & & $1.43(0.93-2.21)$ & \\
\hline Body mass index & & & $<0.001$ * & & $<0.001$ * \\
\hline Underweight & 21.5 & 1.00 & & 1.00 & \\
\hline Normal & 26.4 & $1.22(0.94-1.59)$ & & $1.23(0.95-1.59)$ & \\
\hline Overweight & 27.7 & $1.29(0.99-1.67)$ & & $1.33(1.03-1.71)$ & \\
\hline Obesity & 31.6 & $1.47(1.13-1.94)$ & & $1.49(1.14-1.93)$ & \\
\hline Sedentarism in leisure & & & $<0.001$ & & 0.001 \\
\hline No & 19.6 & 1.00 & & 1.00 & \\
\hline
\end{tabular}

Source: Projeto AQUARES, Universidade Federal de Pelotas, 2009.

* Wald test for linear trend.

Figure 2

Profile and need for health care for the elderly due to falls in Brazil. UFPel, AQUARES, 2009.

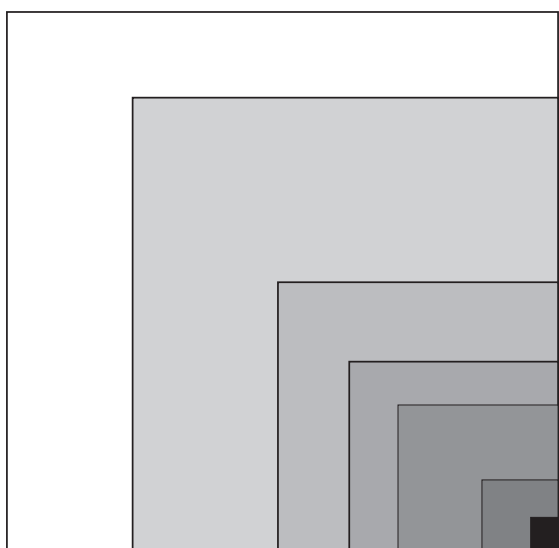

Sample of elderly in Brazil ( $N=6,616 ; 100.0 \%)$

Sedentary leisure $(n=5,722 ; 86.5 \%)$

Overweight and obesity $(n=3,777 ; 57.1 \%)$

Guidance on environmental precautions to prevent falls $(n=2.381 ; 36.0 \%)$

Prevalence of falls in past year $(n=1,826 ; 27.6 \%)$

Fracture from fall $(n=200 ; 3.0 \%)$

Needed surgery due to fracture $(n=49 ; 0.7 \%)$ 
tions targeting these variables, given that they are risk factors that can be modified through the dayto-day activities of health personnel involved with this population group.

As for profiling the need for health care for the elderly as regards falls and consequent fractures, the results presented here show that many associated factors could be minimized through policies to encourage healthier living, through higher levels of physical activity, dietary care, and better guidance on environmental hazards so as to prevent falls. There is a need for inter-sector actions, including investment in urban planning and reorganization of the household environment in the short and medium terms, so as to adjust urban spaces to this population's needs. According to figures for hospital morbidity by place of admission, issued by the data processing department of Brazil's national health service (http:// tabnet.datasus.gov.br/cgi/tabcgi.exe?sih/cnv/ niuf.def, accessed on 16/Mar/2011), in Brazil, 35,426 elderly (60 years or more) were admitted with fracture of the femur (all causes).

\section{Resumo}

Foi realizado um estudo transversal com uma amostra composta de 6.616 idosos, moradores em áreas urbanas de 100 municípios de 23 estados brasileiros, que responderam sobre a ocorrência de quedas no último ano, e consequente fratura devido a quedas. A prevalência de quedas entre os idosos foi de 27,6\% (IC95\%: 26,5-28,7). Entre os que sofreram quedas, $11 \%$ tiveram fratura. Do total de idosos, $36 \%$ haviam recebido orientação sobre os cuidados necessários para evitar quedas, e cerca de 1\% necessitou intervenção cirúrgica. As quedas associaram-se ao sexo feminino, idade avançada, nível socioeconômico E, aos obesos e aos sedentários. A prevalência de quedas na Região Norte mostrou-se significativamente diferente em relação às demais regiões. O estudo mostra que a prevalência de quedas no Brasil é alta e que a promoção de cuidados à saúde dos idosos relacionada a variáveis possíveis de serem modificados é uma necessidade.
Although studies of populations of elderly can raise concerns as regards memory bias, the literature has shown that this bias is small in outcomes such as falls and fractures, because these events are strongly remembered when elderly people are asked, even with a 12-month recall period $12,20,21$.

Finally, our results show that the prevalence of falls is high among the elderly, warranting the conclusion that a high proportion of elderly still suffer falls. Meanwhile, there are still shortcomings in the promotion of health care for the elderly with regard to sedentarism, overweight and obesity, and in guidance on necessary environmental precautions to prevent falls, many of which result in fractures and the need for health care. In that regard, there is an urgent need for more care for this population, including interventions to bring about a reduction in the high rates encountered and promotion of better health conditions in this population group.

\section{Contributors}

F. V. Siqueira participated in the study conception, analyses, interpretation of results, and drafting of the article. L. A. Facchini collaborated in the study conception, and review of the article at its various stages of drafting. D. S. Silveira contributed to the conception, analysis, and review of the article. R. X. Piccini collaborated in the conception, and the final review of the article. E. Tomasi contributed to the final review of the article. E. Thumé collaborated in the literature review, and the final review of the article. S. M. Silva participated in data collection, and final review of the article. A. Dilélio contributed to the literature review, data collection, and final review of the article.

\section{Acknowledgments}

To the Brazilian Ministry of Health. 


\section{References}

1. Organização das Nações Unidas. Plano de ação internacional para o envelhecimento 2002. Brasília: Organização das Nações Unidas; 2003. (Série Institucional em Direitos Humanos, 1).

2. Yu PL, Qin ZH, Shi J, Zhang J, Xin MZ, Wu ZL, et al. Prevalence and related factors of falls among the elderly in an urban community of Beijing. Biomed Environ Sci 2009; 22:179-87.

3. Reyes-Ortiz CA, Al Snih S, Markides KS. Falls among elderly persons in Latin America and the Caribbean and among elderly Mexican-Americans. Rev Panam Salud Pública 2005; 17:362-9.

4. Mota LB, Aguiar AC, Coutinho ES, Huf G. Prevalência e fatores associados a quedas em idosos em um município do Rio de Janeiro. Rev Bras Geriatr Gerontol 2010; 13:83-91.

5. Perracini MR, Ramos LR. Fatores associados a quedas em uma coorte de idosos residentes na comunidade. Rev Saúde Pública 2002; 36:709-16.

6. Siqueira FV, Facchini LA, Piccini LX, Tomasi E, Thumé E, Silveira DS, et al. Prevalência de quedas em idosos e fatores associados. Rev Saúde Pública 2007; 41:749-56.

7. Szwarcwald CL, Damacena GN. Amostras complexas em inquéritos populacionais: planejamento e implicações na análise estatística dos dados. Rev Bras Epidemiol 2008; 11 Suppl 1:38-45.

8. Instituto Brasileiro de Geografia e Estatística. Pesquisa Nacional por Amostras de Domicílios: acesso e utilização de serviços de saúde 2003. Brasília: Instituto Brasileiro de Geografia e Estatística; 2005.

9. Carvalho MP, Luckown ET, Siqueira FV. Quedas e fatores associados em idosos institucionalizados no município de Pelotas, RS. Ciênc Saúde Coletiva; in press.

10. Craig CL, Marshall AL, Sjöström M, Bauman AE, Booth ML, Ainsworth BE, et al. International physical activity questionnaire: 12-country reliability and validity. Med Sci Sports Exerc 2003; 35: 1381-95.
11. Barros AJ, Hirakata VN. Alternatives for logistic regression in cross-sectional studies: an empirical comparison of models that directly estimate the prevalence ratio. BMC Med Res Methodol 2003; $3: 21$.

12. Hallil M, Ulger Z, Cabkurtaran M, Shorbagi A, Yavuz BB, Dede D, et al. Falls and the elderly: is there any difference in the developing world? A crosssectional study from Turkey. Arch Gerontol Geriatr 2006; 43:351-9.

13. Gonçalvez LG, Vieira ST, Siqueira FV, Hallal PC. Prevalência de quedas em idosos institucionalizados do município de Rio Grande, RS. Rev Saúde Pública 2008; 42:938-45.

14. Rozenfeld S, Camacho LAB, Veras RP. Medication as a risk factor for falls in older women in Brazil. Rev Panam Salud Pública 2003; 13:369-75.

15. Pujiula Blanch M, Quesada Sabaté M; Grupo APOC ABS Salt. Prevalencia de caídas en ancianos que viven en la comunidad. Aten Primaria 2003; 32:86-91.

16. Bueno-Cavanillas A, Padilla-Ruiz F, Jimenez-Moleon JJ, Peinado-Alonso CA, Galvez-Vargas R. Risk factors in falls among the elderly according to extrinsic and intrinsic precipitating causes. Eur J Epidemiol 2000; 16:849-59.

17. Lord SR, Menz HB, Sherrington C. Home environment risk factors for falls in older people and the efficacy of home modifications. Age Ageing 2006; 35 Suppl 2: ii55-9.

18. Seculi Sanchez E, Brugulat Guiteras P, March Llanes J, Medina Bustos A, Martinez Beneyto V, Tressera Gaju R. Falls in the elderly: knowing to act. Aten Primaria 2004; 34:186-91.

19. Blake AJ, Morgan K, Bendall MJ, Dallosso H, Ebrahim SB, Arie TH, et al. Falls by elderly people at home: prevalence and associated factors. Age Ageing 1988; 17:365-72.

20. Siqueira FV, Facchini LA, Hallal PC. The burden of fractures in Brazil: a population-based study. Bone 2005; 37:261-6.

21. Dall JO, van Lieshout JJ. Falls and medications in the elderly. Neth J Med 2005; 63:91-6.

Submitted on $30 /$ Nov/2010

Final version resubmitted on 23/Mar/2011 Approved on 05/Abr/2011 